\title{
The Dynamic Relations Between Cultural Identity and Nationhood: The Case of Acehnese Acceptance of and Resistance to Indonesia's State up to Indonesia's Old Order.
}

\author{
Safrudin Amin ${ }^{1}$ \\ \{safrudinamin@gmail.com ${ }^{1}$ \} \\ Department of Social Anthropology, Universitas Khairun Ternate ${ }^{1}$, Kampus II, J1 Jusuf \\ Abdurrahman, Kelurahan Gambesi - Ternate, Maluku Utara.
}

\begin{abstract}
A sociocultural identity of a community is not formed in an empty space. Identity is formed by the interaction of a society with socio-cultural factors in their history. In this study, having a long history as a center of political and military power, a center of Islamic scholarship in the region, a history of bold resistance to the colonial power, internal social revolution in overthrowing aristocrat class, etc., all shaped Aceh's politico-cultural identity. The identity stands on two main cores, Islam and a sense of independence. Shared Islamic identity with other Muslims in Indonesia made Acehnese leaders accepted the idea of being part of Indonesia with one condition that Islam must be the basis of the state. Indeed, to persuade them to agree to be part of Indonesia, Soekarno promised to fulfill that demand. But a few years later the construction of nation-state identity, the development of Indonesian politics, and Soekarno's political stance moved away from Islam. Acehnese saw this not only as a distortion of their identity and hopes but also as a betrayal of the promise given by Soekarno few years earlier.
\end{abstract}

Keywords: Acehnese, identity, nation-state, Islam, Indonesia.

\section{Introduction}

This article is about cultural identity in political arenas called ethnicity and nationalism. In particular, this article deals with the formation of nation-state and its unique politico-cultural dynamics. Anthropological studies on the relations between ethnicity and nationalism have shown various findings which link ethnicity phenomena and nationalism [1], [2], [3]. This article takes the case of Aceh and its dynamic relations with the nation-state of Indonesia.

Historically, Indonesia was not an integrated community. In the pre-colonial period this region consisted of diversity of ethnic groups and cultures. It was the Dutch colonial government that first united the diversity under one single administration. Although the Dutch faced repeated resistance from the local elites whose traditional power were undermined, by the early of the twentieth century the Dutch had successfully incorporated almost all parts of the archipelago under its political. Economic and military control. The colonial government imposed its own administrative system on top of local practices and often resorted to manipulating differences between groups to weaken the local resistance. 
Following the map sketched by Dutch colonial [4], early Indonesian nationalists di Jakarta decided to convince elites of local communities living within the map to accept the idea of one nationhood called Indonesia. In the case of this study, nationalists from Jakarta persuaded Acehnese elites to agree to take Indonesia as their new identity in a wider social scale. This article concerns to answer questions on why the Acehnese who had had their own ethnic-based nationhood identity agreed to be part of Indonesia and how the dynamic relations of these two identities - being Acehnese and being Indonesian - went through the early period of Indonesian nation-state.

This article argues that cultural identity of Acehnese and national identity constructed by nationalists in Jakarta have shaped the dynamic relations between the two identities (Aceh and the new formed nation-state) during the early period of Indonesia. To support the arguments, the first part of this article will map the formation of Acehnese politico-cultural identity, the second will portray the Acehnese's acceptance of Indonesian nations-state, and the third part will discuss the trend of incompatibility between Acehnese identity and the trend of nationhood identity constructed by leaders in Jakarta.

\section{Research Method}

\subsection{Sources and Data Collection}

Although traditionally anthropology has heavily based on gathering primary data in fieldwork, secondary data could also be used for studies on large-scale social phenomena such as nationalism [5]. This study, to a significant extent, is partly a historical anthropology, which aims to integrate archival research with anthropological sensitivity to the complexities of the issue being studied. This study explores the dynamics of politico-cultural identity in a political setting in the past which means the issue being studied is anthropological in nature and method being employed is borrowed from historical research method. In this case, historical method is used as a tool to help an anthropologist to understand his research issue. Data collection is based on the use of documents, mostly secondary sources in the forms of books and journals ${ }^{1}$.

\subsection{Analysis and Study Period}

Genuity (external criticism) and accuracy (internal criticism) of the data are taken for granted since most are written by noted scholars on Aceh and have passed firm academic selection in doctoral degree or strict selection in publication processes both in journal articles and books. The process of reviewing, extracting, and analyzing data is based primarily on the relevancy of particular material to the problem being investigated. To do all the above processes, this study took seven months, intermittently, to finish, from January to July 2019.

\footnotetext{
${ }^{1}$ Secondary sources refer to the documents prepared by those who were not direct witnesses to or participants in an event, but gaining their descriptions from other people.
} 


\section{Result and Discussion}

This section will divide the findings into the formation of Aceh's cultural identity, the negotiation between Acehnese identity and nation-state identity, and the trend of incompatibility of Acehnese identity and the perceived nation-state's trend in the Indonesia's Old Order which resulted in armed resistance in $1950 \mathrm{~s}$.

\subsection{The Formation of Acehnese Cultural Identity}

Acehnese identity has been shaped by several factors, in particular a long history of independence and pre-eminence within the wider Malay world and as a stronghold of Islam. Although Acehnese share many cultural characteristics with other ethnic groups in Sumatra and the Malay Peninsula, they have a strong sense of distinctiveness based upon a perceived glorious past. The golden age of Acehnese culture extends back to the time of the rule of Ali Munghayat Shah (1511 to 1530), Ala'din Riayat Shah al-Kahar (1539 to 1571) and culminated in the reign of Sultan Iskandar Muda 1607 to 1636 [6]. It was during this period that Aceh became the dominant polity in the region, and the major center of commerce and Islamic scholarship. Acehnese power reached its peak under sultan Iskandar Muda with control over the pepper and gold export areas on the West Coast of Sumatra, and over all the key ports. Aceh was one of important commercial centers at that period [7] [8]. He also controlled Pahang, Kedah, and Perak on the Malay Peninsula (now parts of Malaysia) [9], [10].

By the nineteenth century, however, the power of sultanate had declined and control passed into the hands of the local elite, the uleebalang. The rise of the uleebalang coincided with the extension of Dutch power in Sumatra in the 1850s and 1860s. War against the Dutch began in 1873 after increasing Dutch interference in internal Acehnese affairs, particularly related to trade. The war was to last officially until 1903, although resistance continued until 1930s [10]. The 'Aceh War' was the longest and most costly waged by the Dutch during its colonization of the archipelago.

This long war strengthened the Acehnese sense of independent identity. This war, for example, produced many Acehnese heroes such as Tengku Umar and Cut Nyak Dhien. To contemporary Acehnese, these heroes are seen as figures of resistance to outsider control and serve as powerful symbols to Acehnese of their history and identity. In other words, these figures from the colonial war are emblematic of Aceh's long history of independence. These heroes are also officially acknowledged as national heroes of Indonesia.

In Acehnese's eyes the prolonged resistance to the Dutch also marked out their colonial experience as different to other parts of Indonesia. Some Acehnese writers, for example, even claim that Aceh was the only kingdom that never completely surrendered to the Dutch [6]. This perception is also held widely among ordinary Acehnese, which to a significance extent constitutes the way they see themselves in the interaction with the state of Indonesia. This historical basis of Acehnese identity as an independent society has strongly influenced the way more contemporary Acehnese respond to any political developments at the national level.

The second key element of Acehnese identity is Islam. Many Indonesians believe that the first region to embrace Islam in Indonesia was Aceh in the seventh century with the first Islamic kingdom established in ninth century which facilitated the process of Islamization to other parts of the archipelago [11]. Since this period, Aceh has been almost identical with Islam. During the period of Iskandar Muda, for instance, Aceh became a center of Islamic power and scholarship. This was indicated by the fact of the remarkable growing of Islamic learning and 
debate among scholars such as Syek Nuruddin ar-Raniry, Hamzah Fansuri, Syamsuddin Sumathrani, Syek Abdurrauf of Singkel [11].

Although Aceh is a peripheral region in the context of Indonesia, it is certainly not peripheral in terms of Islam. Along with the fact of remarkable Islamic scholarship during the period of the sultanate, Aceh also played an important role in the Islamic world. Acehnese themselves see Aceh "not merely as a bridge between the Islamic centre and the Malay periphery, but as one of the great Islamic sultanates in its own rights" [10].

The strong Islamic identity has also been shaped by the encounter between Aceh and the colonial government that was defined in religious terms. For instance, the war against the Dutch in 1881 was declared a jihad or holy war as the Dutch were believed to be intent on subjugating Islam and Muslim communities.

Internal political conflict between segment of Acehnese society, particularly the uleebalang (local chieftain or local aristocrats) and the ulama (local Muslim scholars), also strengthened the Islamic character of Acehnese society. As previously mentioned the decline of the sultanate facilitated the emergence of uleebalang's power. Although the uleebalang were initially involved in the war against the Dutch, they were gradually co-opted by the colonial government. Morris writes "by 1904 [the uleebalang] were no longer involved in the resistance movement and were being made administrators of the Dutch East Indies government" [12]. Indeed, as Governor Goedhart wrote in 1928 that the Dutch power in Aceh, "aside from the force of arms, depend in the main on the uleebalang" [13]. The uleebalang used their authority under the Dutch to exploit the peasants in the territories under their control. This situation provoked resistance from ulama which resulted in open conflict between uleebalang dan ulama. Ulama continued to lead the resistance against uleebalang and their Dutch masters in the form of continuing guerilla warfare and they also found social, religious and political organizations [14].

As the uleebalang became increasingly alienated from their people and identified with the Dutch, the ulama came to be seen as figures of resistance. This strengthened their influence and supported their efforts to spread Islamic ideology throughout Acehnese society [15]. In this sociocultural position, the ulama were able to determine the construction of religious discourse justifying Acehnese resistance against the colonial power and struggle for liberating Indonesia as a religious call.

\subsection{The Moment of Attachment}

The previous section shows that the strength of Acehnese identity is based on a perception of Aceh as an Islamic community with a long proud history of independence and leadership. The 'golden age' of the sultanates, the reputation as a center of Islamic scholarship and the strong struggle against the Dutch have shaped Acehnese identity and established a sense of Acehnese right to determine their own destiny in accordance with their unique history.

In terms of Islamic identity, as has been discussed, from the very beginning Islam had become one important element in Acehnese society. Acehnese political culture as well as their way of life was heavily based on Islam. The spirit of their struggle for independence and the social revolution to overthrow the uleebalang was also based on Islam. Indeed, the meaning of their support to the republic of Indonesia was embedded in religious (Islamic) meaning.

It was only during the first half of the twentieth century that Acehnese identity was caught up in the nationalist discourse. In this new connection, Acehnese leaders (ulamas), however, defined their struggle against the Dutch not merely as a national struggle against colonialism, 
but as a religious struggle against infidels. Consequently, there was for a time a conflating or co-joining of Acehnese, Indonesian and Islamic aspirations in their nationalist movement.

Probably due to these grounds, Acehnese leaders wanted Indonesia to be an Islamic State. This hope was expressed to Soekarno when he visited Aceh in June 1948. In response Soekarno referred to the Jakarta Charter which assured that the country will apply Islamic law for all Indonesian Muslims, and promised 'to do his best at least to make Aceh an Islamic region' [16], [17]. However, the answer did not fulfil their eagerness to know the future basis of the Indonesian state. "Only when Soekarno re-emphasized that Indonesia would be based on Islamic principles did they give Soekarno their commitment to support the republic" [16]. These facts suggest that Acehnese acceptance of the Indonesian state was based on expectation that Indonesia would be based on Islam and this acceptance of this new identity was formed through an Islamic linkage.

The 'critical junction' [18] between Islamic and nationalistic discourses dominated the Acehnese ulamas and public in the early phase of nation building. In the period after the declaration of independence in 1945, for instance, four prominent ulama, representing all Acehnese ulama launched a declaration that urged Acehnese to support "our great leader, Sukarno" in counteracting the Dutch. In the "Declaration of Ulama Throughout Aceh' they declared a holy war, perang sabil or jihad, against the Dutch stating that the infidels would "try to destroy our pure religion as well as repress and hamper the glory and the prosperity of the Indonesian people" [12]. Since the declaration was promulgated by influential figures, this formal statement had, in one way or another, significant meaning in terms of implanting a sense of belonging to the new nation-state among their huge followers in Aceh and asserting that the sense of belonging was heavily linked to religious considerations. In other words, there was a linking of Acehnese, Indonesia and Islamic aspirations in their struggle against colonialism.

The process of nation-building during this period was determined by the fact that both the nationalists who struggled in Java and those who struggled in outer islands needed each other. The nationalists in Java, for example, sought to incorporate the outlying regions into their vision for an independent Indonesia. Soekarno, one of the leading figures in Java, visited Aceh on several occasions to bring the region on board. In one of his speeches, he referred to Aceh as a 'model region' implying that Aceh was an inspiration in the struggle against colonialism. In the context of nationalism, Acehnese came to see their struggle against infidel colonial power as also a struggle for an independent Indonesia. Viewing themselves as a part of an Indonesianwide youth movement during the nation formation, Acehnese youth used the same Indonesian catchcries of 'merdeka' (freedom) and 'revolusi' (revolution) as used by other Indonesian youth activists, and employed 'Indonesia' in the names of their movement organizations [12].

The ease with which the ulamas were able to bridge Acehnese and Indonesian identity was perhaps due to the links that had been established during the pre-independence period. In the period from 1900-1940, Aceh had been involved in the same mainstream of Islamic developments throughout the archipelago. For instance, in 1913 the influence of Syarikat Islam (Islamic Union) which was founded in 1912 by modernist santris (devout Muslims) in Java reached Aceh [14]. The Muhammadiyah, a reformist Muslim organization also opened a branch in Aceh during this period [10].

\subsection{The Moment of Detachment}

The previous section shows that the confluence between Islam and nationalism in Aceh had made the Acehnese had a strong expectation that the nation-state of Indonesia would be based on Islam. Indeed, the expectation was so high since Soekarno himself had promised to do 
so in his visit to Aceh in 1948. It was only some years after the independence was gained that Acehnese realized that, in the hands of the certain nationalists in Jakarta including Soekarno, who controlled national government policies, their expectation became incompatible.

In the context of the emerging nation-state, Acehnese's expected Islamic identity of the nation-state was challenged by the 'secular' ideology, supported by nominal Muslim politicians and small group of Christians in Jakarta. The ideological battle, in fact, represented a competition between two powerful political cultures in Indonesia, "the Javanese-aristocracy and Islamic-entrepreneurial political cultures" [19]. At the national level, this battle between 'secular' ideology and Islamic ideology was won by the secular one due to the tendency of the central government to take stance against Islamic political orientation. The failure of Islamic ideology has impacted on a political marginalization of Islam in national level.

The marginalization of the Islamic political elite in national polity was clear after the influence of the main Islamic political party, Masyumi, declined and Soekarno tended to support non-Islamic political stance. Javanese priyayi-based party, PNI, dominated cabinet and replaced Masyumi in July 1953 in which the Masyumi party was totally excluded [17]. At that time, Masyumi was one of the major Islamic-based parties, alongside the Javanese-based Nahdatul Ulama (NU). However, unlike NU, Masyumi was regarded as representing the interests of Moslems in the outer islands against Javanese domination from the center [20], Schmitt [21]. At the same time, Masyumi's main political rival, PKI (Indonesian Communist Party) was also increasing its power [10]. As Christie states, "What they particularly resented now was the fact that not only had Aceh been slighted and marginalized, but that Islam -for them the central dynamo of the revolution - had also apparently been sidelined" [10].

What is more, since Islam was the core of their sense of self which determined their aspirations for an Islamic state of Indonesia, the perceived weakening of Islamic power at the national level was seen as a direct attack on their identity. In addition, they also considered national leader in Jakarta, especially Soekarno, had betrayed his promise to Acehnese in 1948 to make Indonesia as a state based on Islam. In Soekarno's speech on 27 January 1953, the president stated that Indonesia was a national, not an Islamic, state. This is perceived as betrayal to Soekarno's own promise to Acehnese. When Soekarno visited Aceh in March 1953, he faced a banner saying "We regret your speech at Amuntai" and "We are heading towards an Islamic State" [16]. Their resentment towards Jakarta was expressed in a letter written on 21 September 1953, the same day the Acehnese rebellion broke out. The letter states:

We've had enough of the developments related to the foundation of the Indonesian state, as from the outset we e $^{\mathrm{e}} \mathrm{ve}$ hoped and longed for a state based on Islam, however instead of its realization it's become increasingly obvious that some Indonesian leaders are trying to lead the state astray [22].

\section{Conclusion}

A nation-state does not emerge in a vacuum context. The construction process of this largescale social formation took a complex process which involve interactions between notions of new social formation and the pre-existing socio-cultural formation such as ethnicities, religions, and regions. Before having an identity as citizens of a nation-state called Indonesia, Acehnese had had their own unique identity composed by history, religion, a sense of being independent community, etc. This article has shown the complex dynamics of relations between ethnic identity, in which Islam is the core of it, and nationhood identity. 
Strong Islamic identity shaping the Acehnese aspiration on the future of Indonesia added by promise proposed by president Soekarno to the Acehnese leaders that the nation-state would be based on Islam had made Acehnese had a high expectation of Acehnese that the new nationstate would be based on Islam. However, Indonesian politics went to opposite direction. This was added by political stance of president Soekarno which clearly showed his undesirable attitude towards Islamic ideology, and this stance confirmed to Acehnese leaders that he had betrayed his promise to them.

When Acehnese found that their identity-based expectation about the basis of Indonesian state was not supported by Soekarno and the political trend under Sukarno's control, they became aware that they had made a wrong decision to be part of Indonesia and to believe Soekarno's promise in 1948. Their decision was to detach Aceh from Indonesia by declaring rebellion against the central government in 1953.

Acknowledgements. I would like to thank to late Ms Sri Wahyuni, a friend from Acehnese, for sharing some materials on Aceh. I also thanks to some friends for insightful and roductive discussions on Aceh which had contributed much to the elaboration of this article.

\section{References}

[1] Eriksen. T. H.: Ethnicity and Nationalism: Anthropological Perspectives. (London: Pluto Press), pp. 59-120 (1993)

[2] Eriksen, T. H.: Ethnicity and Nationalism: Anthropological Perspectives (3rd). (London: Pluto Press) pp. 70-146 (2010)

Gellner,E Nations and Nationalism. USA: Cornell University Press. pp. 39-62 (1983)

[4] Anderson. B. Imagined Communities: Reflection on the Origin and Spread of Nationalism (London: Verso).pp. 163-186 (2006)

[5] B. Kapferer.: Legends of People Myths of State Violence, Intolerance, and political Culture in Sri Lanka and Australia (Washington: Smithsonian Institution Press).PP.11.(1988)

[6] Thaib, 1.: Aceh Sumatra dalam Dimensi Sejarah (Selangor: Asni Sdn Bhd).PP.1-25 (1997)

[7] Sulistiyanto P.:Whither Aceh Third World Quarterly, Vol 22.pp. 437-452 (2001)

[8] Reid A.: War, Peace and the Burden of History in Aceh Asian Ethnicity, Vol 5.pp. 301-314 (2004)

[9] Kell, T. .: The Roots of Acehnese Rebellion, 1989-1992 (New York: Cornell Modern Indonesia Project).pp. 3-12 (1995)

[10] Christie, C. J.: A Modern History of Southeast Asia: decolonization, nationalism and separatism. London: I.B. Taurus Publishers.pp. 140-152 (1996)

[11] Hasjmy, A. .: Kebudayaan Aceh dalam Sejarah (Jakarta: Beuna).pp. 36-49 (1983)

[12] Morris.: Aceh Social Revolution and Islamic Vision, ed. A. R. Kahin, in Regional Dynamics of the Indonesian Revolution: Unity from Diversities (Honolulu: University of Hawaii Press) pp. 83$110(1985)$

[13] Tarling, N.: Nations and States in Southeast Asia (Cambridge: Cambridge University Press),Pp. 59 (1998)

[14] Hasjmy, A. : Perang Gerilya dan Pergerakan Politik di Aceh untuk Merebut Kemerdekaan Kembali (Banda Aceh: MUI Aceh).pp.1-16 (1980)

[15] Siegel J. T.: The Rope of God (Berkeley: University of California Press), pp. 71(1969)

[16] Sjamsuddin, N. : The Republican Revolt: a Study of the Acehnese Rebellion. Singapore: Institute of Southeast Asian Studies Heng Mui Keng Terrace.pp. 30 (1985)

[17] Brown, D. : Neo-patrimonialism and national integration in Indonesia, ed. David Brown, in The State and Ethnic Politics in Southeast Asia (London: Routledge), pp. 112-157 (1994) 
[18] Kalb D. and H. Tak.: Critical Junctions (New York: Berghahn Books).pp. 1-25 (2005)

[19] Feith, H.: The Decline of Constitutional Democracy in Indonesia (New York: Cornell University Press)pp.30 (1962)

[20] McVey R.. Building Behemoth: Indonesian Constructions of the Nation-State, eds. D.S. Lev and R. McVey, in Making Indonesia. Ithaca (New York: Cornell Southeast Asia Program Publications).pp. 11-25 (1996)

[21] Schmitt, H. O.: Foreign Capital and Social Conflict in Indonesia, 1950-1958, Economic Development and Cultural Change, Vol 10.pp. 284-293 (1962)

[22] Talsya, Sedjarah dan Dokumen-dokumen Pembrontakan di Atjeh (Jakarta: Kesuma) pp. 67 